\title{
EFFECT OF HEPATITIS-B VIRUS CO-INFECTION ON CD4 CELL COUNT AND LIVER FUNCTION OF HIV INFECTED PATIENTS
}

\author{
H.O. OLAWUMI ${ }^{1}$, D.O. OLANREWAJU ${ }^{2}$, A.O. SHITTU $^{1}$ I.A. DUROTOYE $^{1}$ A.A. AKANDE ${ }^{3}$ and \\ A. NYAMNGEE ${ }^{4}$ \\ ${ }^{1}$ Department of Haematology, University of Ilorin, Ilorin, Nigeria, ${ }^{2}$ Department of Haematology and Blood \\ Transfusion, Ambrose Alli University, Ekpoma, Nigeria, ${ }^{3}$ Department of Chemical Pathology and \\ Immunology, University of Ilorin, Ilorin, Nigeria, ${ }^{4}$ Department of Microbiology and Parasitology, \\ University of Ilorin, Ilorin, Nigeria.
}

DOI: http://dx.doi.org/10.4314/gmj.v48i2.7

Corresponding Author: Dr. H.O Olawumi

Email: toyem66@yahoo.com

Conflict of Interest: None declared

\section{SUMMARY}

Background: Human immunodeficiency virus (HIV) and Hepatitis B virus (HBV) share similar routes of transmission, making it possible for an individual to have a co-infection. HBV infection is well known to be a major cause of chronic liver diseases worldwide. The aim of this study was to determine the prevalence of HBV infection among HIV infected HAART naïve patients and investigate the effect of co-infection on CD4 count and liver function.

Study design: This was a hospital based descriptive cross sectional study of one hundred consecutive therapy-naive HIV-infected individuals. The CD4 count, Hepatitis B surface antigen, Serum albumin, total Protein, and liver enzymes were determined using standard techniques.

Results: The prevalence of HIV and HBV co-infection was $37 \%$. The mean serum ALT and ALP were significantly higher in the co- infected patients (P-values $<0.05)$. The mean CD4 count of the mono infected patients was significantly higher ( $p$-value of 0.014 ). The mean serum ALT, AST and ALP of mono and coinfected patients with CD4 count $<200 / \mu 1$ were significantly higher than those with count $\geq 200$ cells $/ \mu 1$. (pvalue of $<0.01$ ). The mean ALT and AST of the co infected patients and all patients with CD4 count $<200$ cells/ $\mu$ l were higher than the normal reference range.

Conclusion: Approximately one third of HIV positive patients had hepatitis $\mathrm{B}$ virus co-infection. Coinfection and CD4 count $<200$ cells/ $\mu 1$ are likely to result in abnormal ALT and AST. We recommend those co-infected patients and those with CD4 count $<200$ cells/ $\mu 1$ should be given non-hepatotoxic antiretroviral drug.

Keywords: HIV, Hepatitis B, CD4 count, liver function, co-infection

\section{INTRODUCTION}

Human immunodeficiency virus (HIV) and Hepatitis B virus (HBV) share similar routes of transmission, making it possible for an individual to have co-infection. The common routes of transmission vary from place to place depending on the degree of endemicity of HBV. In areas of low endemicity, such as North America, Australia and Europe, HBV and HIV infection are usually acquired in adulthood through sexual or percutaneous transmission. In countries with intermediate and high HBV endemicity like Nigeria, the main routes of transmission of HBV and HIV are vertical in children and through sexual intercourse in adults. The prevalence of chronic co-infection among HIV-infected individuals is around $5-7 \%$ and $10-20 \%$ respectively in countries with low and those with intermediate/high HBV endemicity respectively. ${ }^{1-4}$

Hepatitis B virus infection is a major cause of chronic liver diseases including cirrhosis and hepatocellular carcinoma worldwide. The progression of hepatic complications from HBV infection is accelerated in patients co-infected with HIV. ${ }^{5,6}$ This is particularly so in HIV infected men with very low CD4 count. ${ }^{7}$ In addition, HIV infected individuals are more likely to lose previously developed protective anti-HBs antibody and develop acute hepatitis $\mathrm{B}$ infection; this risk is also associated with lower CD4 counts. ${ }^{8}$ The risk of hepatocellular carcinoma (HCC) in HIV infected patients who are co-infected with hepatitis B virus is also increased in individuals with lower CD4 counts. ${ }^{9}$

Hepatic toxicity is a common complication in HIVinfected patients on Highly Active Antiretroviral Therapy (HAART). ${ }^{10}$ Patients who had viral hepatitis in addition to HIV were found to be about 4 times more likely to develop severe hepatic toxicity associated with antiretroviral drug. 
This has been attributed to HAART induced immune reconstitution inflammatory syndrome (IRIS). ${ }^{11,12} \mathrm{Be}-$ cause of the HAART induced IRIS which usually leads to worsening of liver disease including hepatic decompensation, the actual effect of HBV and HIV coinfection on liver function is best studied in HAART naive patients.

The aim of this study was to determine the prevalence of HBV infection among HIV-infected HAART naive patients and investigate the effect of co-infection on CD4 count and liver function of the patients.

\section{PATIENTS AND METHODS}

Patients included in this study were the first 100 consecutive therapy-naive HIV - infected individuals attending the HAART clinic at University of Ilorin Teaching Hospital, Ilorin between January and December 2010. University of Ilorin Teaching Hospital Ethical Review Committee which is a member of the National Health Research Ethics Council approved the study protocol. Written Informed consent of the participants was equally obtained. Patients that did not consent to participate in the study were excluded. This research received no specific grant from any funding agency in the public, commercial, or not-for-profit sectors. There is no other conflict of interest whatsoever.

HIV positivity was diagnosed by positive reactions to two different enzyme linked immunosorbent assays (ELISA). Hepatitis B surface antigen test was done using ELISA method. All the ELISA assays were done using kits manufactured by Bio-Rad Laboratories, Inc., Berkeley, California. The CD4 cell count was determined using Dynal T4 Quant (Dynal Biotech ASA, Oslo, Norway). Laboratory assessment of liver functions was determined by liver Enzymes - mainly Alanine amino transferase (ALT), Aspartate amino transferase (AST), Alkaline phosphtase (ALP) and albumin as a synthetic function.

Serum Albumin and Total protein were determined with Randox kit (Randox Laboratory limited, Ardmore, UK) using the Bromo Cresol Green (BCG) ${ }^{13}$ and Biu$\operatorname{ret}^{14}$ methods respectively. Normal ranges were 35$50 \mathrm{~g} / 1$ and $60-80 \mathrm{~g} / 1$ respectively. ALT, AST and ALP were determined with Agappe Kit (Agappe Diagnostics, Switzerland $\mathrm{GmbH})^{15}$ Normal ranges were 015IU/L, 0-23IU/L and 21-91IU/L respectively.Data was analysed using SPSS version 15 . Statistical analysis of mean and standard deviation were used for the numeric variables. Mean of the CD4 count and the various parameters of liver function test of the Hepatitis B surface antigen (HBsAg) positive and negative patients were compared by the student t-test. Differences were regarded as significant when $\mathrm{P} \leq 0.05$.

\section{RESULTS}

One hundred HIV patients (35 males and 65 females) aged $37 \pm 9$ years $($ mean $\pm \mathrm{SD})$ were recruited for this study. Thirty seven (37\%) were hepatitis B positive while $63(63 \%)$ were negative. Twenty four $(64.9 \%)$ of the HBsAg patients were females while $13(35.1 \%)$ were males. Majority i.e. $52 \%$ of the patients presented at stage 3 and only $20 \%$ presented at stage 1 (Table 1).

\section{Effect of Hepatitis B virus co-infection on CD4 cell} count and liver function of HIV infected patients

The mean CD4 count of all the patients was 212 $\pm 188 / \mu 1$. The mean serum levels for ALT, AST, ALP, total protein and albumin for the study population were $17 \pm 23 \mathrm{IU} / \mathrm{L}, 25 \pm 24 \mathrm{IU} / \mathrm{L}, 56 \pm 64 \mathrm{IU} / \mathrm{L}, 75 \pm 9 \mathrm{~g} / 1$ and $38 \pm 7 \mathrm{~g} / 1$ respectively.

Table 1 Stage of disease at diagnosis and HBsAg status

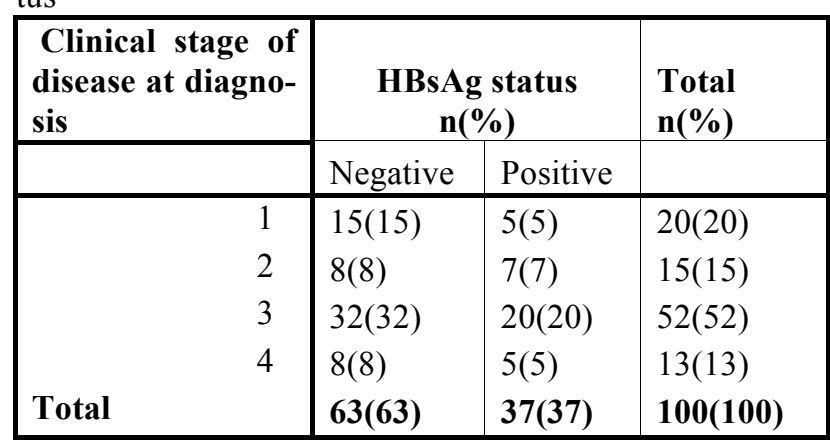

The mean levels of liver enzymes, serum albumin and total proteins of the HIV mono infected patients were all within the normal reference ranges. In the coinfected patients, ALT and AST were higher than normal but the other parameters were within the normal reference ranges. The mean serum level of ALT and ALP were significantly higher in the co infected patients than in the HIV mono infected patients, P-values of 0.043 and 0.042 respectively.

Table 2 Biochemical parameter and CD4 count in HBsAg positive and negative patients

\begin{tabular}{|l|l|l|l|l|}
\hline Parameter & $\begin{array}{l}\text { HBsAg } \\
\text { negative } \\
(\mathrm{m} \pm \mathrm{sd})\end{array}$ & $\begin{array}{l}\text { HBsAg } \\
\text { positive } \\
(\mathrm{m} \pm \mathrm{sd})\end{array}$ & $\begin{array}{l}\text { Mean differ- } \\
\text { ence }\end{array}$ & P-value \\
\hline ALT(UI/L) & $13.86 \pm 19.8$ & $23.32 \pm 26.1$ & 9.4672 & 0.043 \\
\hline AST(UI/L) & $21.95 \pm 23.5$ & $29.84 \pm 25.1$ & 7.8855 & 0.118 \\
\hline ALP(UI/L) & $45.76 \pm 55.2$ & $72.95 \pm 75.3$ & 27.1878 & 0.042 \\
\hline $\begin{array}{l}\text { Total protein } \\
(\mathrm{g} / \mathrm{l})\end{array}$ & $75.68 \pm 11.6$ & $74.50 \pm 9.7$ & 1.1825 & 0.606 \\
\hline Albumin( (g/l) & $37.62 \pm 6.5$ & $37.75 \pm 7.2$ & 0.1310 & 0.927 \\
\hline $\begin{array}{l}\text { CD4 count } \\
(\text { cells/ } \mu 1)\end{array}$ & $\begin{array}{l}247.19 \pm \\
209.7\end{array}$ & $\begin{array}{l}152.14 \\
\pm 123.9\end{array}$ & -95.0553 & 0.014 \\
\hline
\end{tabular}

Normal reference values: Serum albumin (35-50g/1), Total protein (60-80g/l), ALT (0-15IU/L), AST (0-23IU/L) and ALP(21-91IU/L) 
The higher level of AST among co infected patients compared to the HIV mono infected patients was not statistically significant (p-value of 0.11 ) and there was no significant difference in the levels of total protein and albumin between the co infected and mono infected patients (Table 2)The mean CD4 count of the mono infected patients was significantly higher than that of the co-infected patients ( $\mathrm{p}$-value of 0.014 ). Table 2

The mean levels of all the liver enzymes, serum albumin and total proteins of the all HIV infected patients with CD4 count $\geq 200 / \mu 1$ were all within the normal reference ranges for the laboratory. For those with CD4 count below 200/ $\mu 1$ the mean ALT and AST were higher than normal but the other parameters were within the normal reference ranges.

Table 3 Biochemical parameters in patients with CD4 count above and below 200 cells $/ \mu 1$

\begin{tabular}{|c|c|c|c|c|c|c|}
\hline & $\begin{array}{l}\text { CD4 } \\
\text { count } \\
(\text { cells } / \mu \mathrm{l})\end{array}$ & $\mathbf{N}$ & Mean & $\begin{array}{l}\text { Std. } \\
\text { Devia- } \\
\text { tion }\end{array}$ & $\begin{array}{l}\text { Mean } \\
\text { differ- } \\
\text { ence }\end{array}$ & p-value \\
\hline ALT(UI/L) & $\begin{array}{l}>=200 \\
<200\end{array}$ & $\begin{array}{l}37 \\
63 \\
\end{array}$ & $\begin{array}{l}13.000 \\
19.921\end{array}$ & $\begin{array}{l}11.5326 \\
26.9577\end{array}$ & -6.9206 & 0.000 \\
\hline AST(UI/L) & $\begin{array}{l}>=200 \\
<200\end{array}$ & $\begin{array}{l}37 \\
63\end{array}$ & $\begin{array}{l}17.946 \\
28.937\end{array}$ & $\begin{array}{l}16.4805 \\
27.2041\end{array}$ & $\begin{array}{l}- \\
10.9906\end{array}$ & 0.002 \\
\hline ALP(UI/L) & $\begin{array}{l}>=200 \\
<200\end{array}$ & $\begin{array}{l}36 \\
63\end{array}$ & $\begin{array}{l}43.944 \\
62.762\end{array}$ & $\begin{array}{l}45.2364 \\
71.4983\end{array}$ & $\begin{array}{l}- \\
18.8175\end{array}$ & 0.008 \\
\hline $\begin{array}{l}\text { Total protein } \\
(\mathrm{g} / \mathrm{l})\end{array}$ & $\begin{array}{l}>=200 \\
<200\end{array}$ & $\begin{array}{l}36 \\
63 \\
\end{array}$ & $\begin{array}{l}72.722 \\
76.698 \\
\end{array}$ & $\begin{array}{l}10.0644 \\
11.1668 \\
\end{array}$ & -3.9762 & 0.637 \\
\hline $\begin{array}{l}\text { Albumin } \\
(\mathrm{g} / \mathrm{l})\end{array}$ & $\begin{array}{l}>=200 \\
<200\end{array}$ & $\begin{array}{l}36 \\
63\end{array}$ & $\begin{array}{l}37.750 \\
37.619\end{array}$ & $\begin{array}{l}6.3308 \\
7.0400\end{array}$ & -0.1310 & 0.839 \\
\hline
\end{tabular}

Normal reference values: Serum albumin (35-50g/1), Total protein (60-80g/1), ALT (0-15IU/L), AST (0-23IU/L) and ALP(21-91IU/L)

The mean serum level of ALT, AST and ALP of patients with CD4 count below 200/ 1 l were significantly higher than the mean of those with CD4 count $\geq$ $200 / \mu 1$. (p-value of $<0.01$ in each case) Table 3

The mean level of AST of the male co-infected patients was significantly higher than their female counterparts (p-value of 0.007) but there was no significant difference in their ALT, ALP, serum albumin and total protein level.

Among the HIV mono-infected patients significant difference was found only in the ALT level in which case the mean value in males was significantly higher than in female ( $p$-value of 0.047) (Table 4)
Table 4 Sex comparison of biochemical parameters among co-infected and mono-infected patients

\begin{tabular}{|c|c|c|c|c|c|c|}
\hline \multirow{2}{*}{$\begin{array}{l}\text { param- } \\
\text { eters }\end{array}$} & \multicolumn{3}{|c|}{ Co-infected patients } & \multicolumn{3}{|c|}{ Mono-infected patients } \\
\hline & male & female & $\begin{array}{l}\mathrm{p}- \\
\text { value }\end{array}$ & Male & female & $\begin{array}{l}\mathrm{p}- \\
\text { value }\end{array}$ \\
\hline ALT & $\begin{array}{l}19.5 \pm 19 \\
.7\end{array}$ & $\begin{array}{l}25.4 \pm 29 . \\
2\end{array}$ & 0.463 & $\begin{array}{l}18.0 \pm 2 \\
9.1\end{array}$ & $\begin{array}{l}11.6 \pm 12 \\
.1\end{array}$ & 0.047 \\
\hline AST & $\begin{array}{l}37.6 \pm 33 \\
.1 \\
\end{array}$ & $\begin{array}{l}25.6 \pm 19 . \\
1\end{array}$ & 0.007 & $\begin{array}{l}21.7 \pm 2 \\
7.4\end{array}$ & $\begin{array}{l}22.1 \pm 21 \\
.6\end{array}$ & 0.921 \\
\hline ALP & $\begin{array}{l}67.8 \pm 82 \\
.9 \\
\end{array}$ & $\begin{array}{l}75.8 \pm 72 . \\
6\end{array}$ & 0.758 & $\begin{array}{l}46.5 \pm 6 \\
9.7\end{array}$ & $\begin{array}{l}45.3 \pm 46 \\
.4\end{array}$ & 0.636 \\
\hline $\begin{array}{l}\text { Albu- } \\
\text { min }\end{array}$ & $\begin{array}{l}35.2 \pm 8 . \\
2\end{array}$ & $39.2 \pm 6.4$ & 0.404 & $\begin{array}{l}37.9 \pm 7 \\
7\end{array}$ & $\begin{array}{l}37.5 \pm 5 . \\
9\end{array}$ & 0.363 \\
\hline $\begin{array}{l}\text { Total } \\
\text { protein }\end{array}$ & $\begin{array}{l}72.2 \pm 8 \\
9\end{array}$ & $\begin{array}{l}75.8 \pm 10 . \\
0\end{array}$ & 0.775 & $\begin{array}{l}78.0 \pm 1 \\
0.7\end{array}$ & $\begin{array}{l}74.4 \pm 12 \\
.0\end{array}$ & 0.290 \\
\hline
\end{tabular}

\section{DISCUSSION}

Hepatitis B virus is a major cause of chronic liver disease worldwide. Hepatic toxicity is also a well-known complication of treatment of HIV infection with HAART. Accurate assessment of HBV infection in HIV co-infected individuals is necessary in order to make therapeutic decisions. ${ }^{6}$ World Health Organization (WHO) advocates $\mathrm{HBsAg}$ testing especially in areas of high $\mathrm{HBV}$ prevalence, but additional testing for HBV markers such as HBeAg and HBV DNA and tests to assess stage of liver disease (e.g. liver enzymes, liver biopsy, etc) may not be widely available in many resource limited countries. ${ }^{16}$

In most of the centres where HIV/AIDS patients are being managed in Nigeria the HBsAg and assay of liver enzymes are done routinely before commencement of HAART. This is to help the physician to decide on the appropriate regimen in terms of avoiding those that are hepatotoxic in patients who already have derangement of the liver function and also the use of drugs that are also effective against HBV for HBsAg positive patients.

The prevalence of HBV infection among HIV infected HAART naive patients in this study was $37 \%$. This is higher than the prevalence in other countries with high HBV endemicity. ${ }^{1-4}$

This study has shown that the level of serum ALT and ALP is higher in HIV and HBV co-infected patients compared to HIV mono-infected patients. This is consistent with a previous study done in Nigeria and South Tamil Nadu . ${ }^{17,18}$

This study has also shown that CD4 count of the HIV mono-infected patients was significantly higher than that of the patients co-infected with HBV. 
Furthermore, mean serum level of ALT, AST and ALP of patients with CD4 count below 200/ $\mu$ l were significantly higher than in those with CD4 count $\geq 200 / \mu 1$. In a prospective longitudinal cohort study with subjects recruited from US, Australia and Thailand, it was found that the prevalence of hepatotoxicity at baseline was about $13 \%$ and that CD4 count $<200$ cells $/ \mathrm{mm}^{3}$ and HBV DNA > $2000 \mathrm{IU} / \mathrm{ml}$ were significantly associated with an increased risk of significant hepatotoxicity among HIV/HBV co-infected people on long-term HAART. ${ }^{19}$

The serum levels of ALT and AST among mono- and co-infected patients respectively were significantly higher among male patients than in female patients. This difference was much more significant among the co-infected patients and therefore confirms previous studies that suggested that HIV infection accelerated the progression to hepatic complications in HBV infected men. $^{5,6}$

Routine estimation of Alanine aminotransferase (ALT) is an inexpensive and non-invasive means of assessing liver disease as it reflects the activity of hepatotropic viruses and status of liver during therapy with various hepatotoxic drugs. Even though it is well known that ALT may even be normal in the presence of advanced liver disease, in resource limited countries like Nigeria it still remains the affordable test in the assessment of liver function in the management of HIV/AIDS patients.

Elevated ALT at baseline is an indication that the liver is already compromised and so drugs that are hepatotoxic will have to be avoided in order not to further compromise the liver function. Those with co-infection with $\mathrm{HBV}$ are usually given drugs that are also effective for treatment of HBV.

Baseline CD4 count which used to be a standard requirement for commencement of antiretroviral therapy may also be used as a surrogate test for liver function especially in co-infected patients. So that even if the ALT is normal a low CD4 count below 200 may be a signal for performing more sensitive or invasive test to assess the function of the liver.

\section{CONCLUSION}

In conclusion, the prevalence of HBV infection among HIV infected HAART naive patients in this study were higher than in previous studies. Hepatitis B virus coinfected HIV positive patients are more likely to have abnormal liver function test than the mono-infected patients. HIV infected patients with CD4 below 200/ $\mu 1$ are also more likely to have abnormal liver function than those with CD4 count above 200cells/ $\mu 1$.
We recommend that hepatitis B virus co-infected HIV positive patients should be given first-line antiretroviral drugs that are non- hepatotoxic. Patients with CD4 count below 200cells/ $\mu$ l should also be given non hepatotoxic antiviral drugs regardless of their HBsAg status.

\section{REFERENCES}

1. Alter MJ. Epidemiology of viral hepatitis and HIV co infection. J Hepatol. 2006; 44(1 Suppl):S6-9.

2. Lee HC, Ko NY, Lee NY et al. Seroprevalence of viral hepatitis and sexuallytransmitted disease among adults with recently diagnosed HIV infection inSouthern Taiwan, 2000-5: upsurge in hepatitis $\mathrm{C}$ virus infections among injection drug users. J Formos Med Assoc. 2008; 107:404 - 11.

3. Diop-Ndiaye H, Toure-Kane C. Hepatitis B, C seroprevalence and deltavirus in HIV-1 Senegalese patients at HAART initiation (retrospective study). J Med Virol. 2008; 80:1332 - 6.

4. Nyirenda M, Beadsworth MB, Stephany $\mathrm{P}$ et al. Prevalence of infection with hepatitis $\mathrm{B}$ and $\mathrm{C}$ virus and co infection with HIV in medical inpatients in Malawi. J Infect. 2008; 57:72-77

5. Puoti M, Torti C, Bruno R et al. Natural history of chronic hepatitis B in co-infected patients. J Hepatol. 2006; 44:65 -70.

6. Thio, C. Hepatitis B and Human Immunodeficiency Virus Co infection. Hepatol.2009; 49:138 -145

7. Bodsworth NJ, Cooper DA, Donovan B. The influence of human immunodeficiency virus virus type 1 infection on the development of the hepatitis B carrier state. J Infect Dis. 1991; 163:1138 40 .

8. Biggar RJ, Goedert JJ, Hoofnagle J. Accelerated loss of antibody to hepatitis B surface antigen among immunodeficient homosexual men infected with HIV. N Engl J Med. 1987; 316: 360.

9. Clifford GM, Rickenbach M, Polesel J et al. Influence of HIV-related immunodeficiency on the risk of hepatocellular carcinoma. AIDS. 2008; 22:2135 -41 .

10. Akande AA, Olaosebikan OF, Jimoh AK, Abdulazeez, Olawumi HO. Lamivudine therapy and hepatotoxicity as seen in a Nigerian tertiary antiretroviral treatment centre. Afr. J. of Biochem Res. 2007;1(6): 90 - 94

11. Hoffman CJ, Thio CL. Clinical implications of HIV and hepatitis B co infection in Asia and Africa. Lancet Infect Dis. 2007; 7: 402 - 9.

12. Drake A, Mijch A, Sasadeusz J. Immune reconstitution hepatitis in HIV and hepatitis B co infection, despite lamivudine as part of HAART. Clin Infect Dis. 2004; 39:129-132. 
13. Tietz NW. Clinical Guide to Laboratory Tests. $3^{\text {rd }}$ Edition.(1995)WBSaundersCompany. Philadephia. PA. Pg 518-519

14. Weichselbaum TE. American Journal of Clinical Pathology. 16: Pg 40

15. Klin Z. Chem. KlinBiochemistry 1980; 8658:10, Pg. 182.

16. WHO. Antiretroviral therapy for HIV infection in adults and adolescents:recommendations for a public health approach. Geneva, Switzerland, 2006.

17. Otegbayo JA, Taiwo BO, Akingbola TS et al. Prevalence of hepatitis $\mathrm{B}$ and $\mathrm{C}$ seropositivity in a Nige- rian cohort of HIV-infected patients. Ann Hepatol. 2008; 7(2):152-6

18. Ganesh KA, Sridharan K, Thirunalasundari T. Seroprevalence of $\mathrm{HCV}$ and its co-infection with HBV and HIVamong liver disease patients of South Tamil Nadu. World J Hepatol. 2010; 2(1):42-48.

19. Audsley J, Seaberg E, Sasadeusz J. Factors Associated with Hepatotoxicity in an International HIV/HBV Co-infected Cohort on Long-term HAART. 17th Conference on Retroviruses \& Opportunistic Infections (CROI 2010). San Francisco. February 16-19, 2010. (Abstract 691). 